\title{
ИНВЕСТИЦИОННОЕ СТРАХОВАНИЕ ЖИЗНИ
}

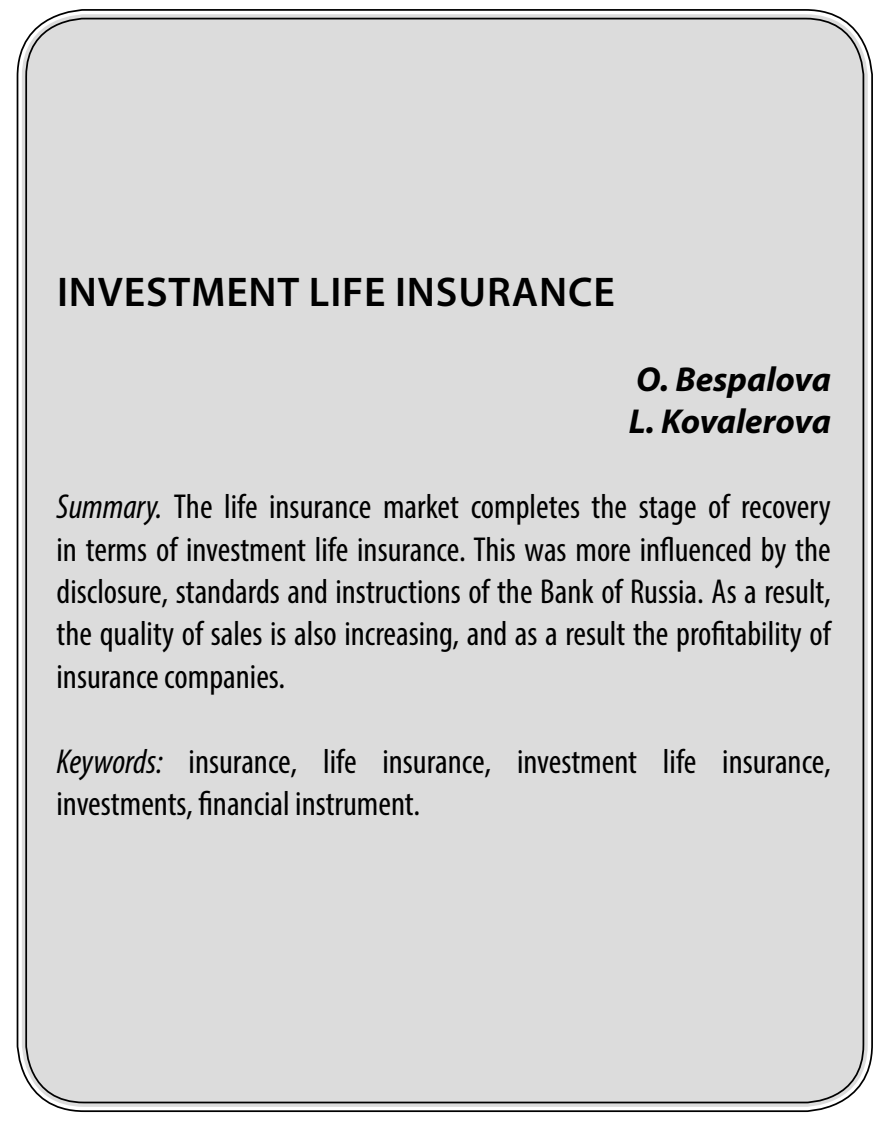

$\mathbf{P}$ ынок страхования жизни развивается в неблагоприятной экономической ситуации. Исходя из отчетов Банка России видно, что доля жалоб на услуги по страхованию жизни выросла до 4\%.

Для того, чтобы приобретать страховые услуги необходимо иметь хороший уровень доходов и определенные сбережения. Рынокхарактеризуется преобладанием страхователей старше 50 лет. Как показывает статистика, динамика реальных доходов населения в России отрицательна. За последние годы доходы сократились на 8,5\%. Норма доходов направляемых на увеличение сбережений в России также падает [5].

91\% россиян имеют доход ниже 25 тыс. рублей, 7,5\% имеют доход от 25 до 50 тыс. рублей и всего 1,5\% населения имеют доход свыше 50 тыс. рублей. Кроме того, большая часть населения не имеет никаких сбережений. Имеют накопления только 41\% граждан. Средний размер сбережений от 140 до 200 тыс. рублей.

Из данных представленных в таблице 1, видно, что в структуре сбережений граждан наибольший удельный вес приходится на депозиты в рублях (46,8\%), депозиты
Беспалова Ольга Васильевна

К.э.н., старший преподаватель, Брянский государственный университет имени акад.

И. Г. Петровского

bespalovaov@yandex.ru

Ковалерова Людмила Анатольевна

К.э.н., дочент, Брянский государственный университет имени акад. И. Г. Петровского kovaleroval@mail.ru

Аннотация. Рынок страхования жизни завершает стадию оздоровления В части инвестиционного страхования жизни. В большей степени на это повлияло раскрытие информации, стандарты и указания Банка России. Вследствие чего растет качество продаж, а в результате и доходность страховых компаний.

Ключевые слова: страхование, страхование жизни, инвестиционное страхование жизни, инвестиции, финансовый инструмент.

в валюте (13\%) и наличные деньги в рублях (13\%) и валюте (7\%) [6].

Инвестиционное страхование жизни - продукт, объединяющий страхование жизни и финансовый инструмент, позволяющий получить доход за счет инвестирования средств в различные финансовые активы.

Срок страхования составляет, как правило, от трех до пяти лет. Оплата страхового взноса производится либо единовременно, либо ежемесячно, ежегодно.

Страховые взносы делятся на гарантированную и инвестиционную части. Гарантированная часть инвестируется в консервативные финансовые инструменты, а инвестиционная в инструменты с высоким уровнем дохода и риска одновременно. Таким образом, инвестиционное страхование жизни не дает гарантий на получение дохода [1].

Инвестиционное страхование жизни является одним из популярных финансовых инструментов. Страховые взносы по данному направлению превышают 300 млрд. рублей. 
Таблица 1. Структура сбережений граждан России, 2019 год

\begin{tabular}{|l|l|l|}
\hline Вид сбережений & млрд. руб. & $\%$ \\
\hline Вклады в рублях & 21793 & 46,8 \\
\hline Вклады в валюте & 6061 & 13,0 \\
\hline Наличные рубли & 6071 & 13,0 \\
\hline Наличная валюта & 3250 & 7,0 \\
\hline Ценные бумаги & 5021 & 10,8 \\
\hline Средства в НПФ & 2667 & 5,7 \\
\hline Средства в ПИФ & 755 & 1,6 \\
\hline Средства в страхование жизни & 928 & 2,0 \\
\hline Итого & 46546 & 100 \\
\hline
\end{tabular}

Таблица 2. Достоинства и недостатки инвестиционного страхования жизни

Достоинства
\begin{tabular}{|l|l|}
\hline $\begin{array}{l}\text { 1. Налоговая льгота в размере 13\% от страхового взноса. } \\
\text { Отсутствие обязательств уплаты налогов. }\end{array}$ & $\begin{array}{l}\text { 1. Досрочное расторжение договора страхования с возвратом } \\
\text { страховых взносов невозможно. }\end{array}$ \\
\hline $\begin{array}{l}\text { 2. Средства не могут быть конфискованы, не могут быть взысканы } \\
\text { по суду, на них не может быть наложен арест. }\end{array}$ & 2. Отсутствие гарантированного дохода. \\
\hline $\begin{array}{l}\text { 3. Договор страхования может быть заключен в пользу любого } \\
\text { лица. }\end{array}$ & $\begin{array}{l}\text { 3. Отсутствие гарантийного фонда, который бы являлся «подушкой } \\
\text { безопасности» в случае проблем у страховщика. }\end{array}$ \\
\hline
\end{tabular}

Доход по данному виду страхования напрямую зависит от результативности инвестирования средств клиентов.

Высоких доходностей на рынке акций за истекший период не наблюдалось. Глобальный рынок акций показал минусовые значения $(-11,2 \%)$. Рынок акций США показал умеренное снижение (индекс S\&P 500-6,2\%). На развивающихся рынках аутсайдерами стали Китай $(-19,8 \%)$ и Турция $(-20,9 \%)$. Лидерами роста стали: Катар $(+21,2 \%)$, Тунис $(+15,8 \%)$ Бразилия $(+15,0 \%)$, Россия $(+8,1 \%)[7]$.

По отраслям лучшую динамику показали здравоохранение $(+0,2 \%)$, а также IT-сектор. Лидерами падения стали добывающая промышленность $(-18,1 \%)$, финансы $(-17,9 \%)$, энергетика и обрабатывающая промышленность $(-15,8 \%)$ [4].

Доходность рынка облигаций оказалась сравнительно лучше доходности рынка акций. Индексы на рынок облигаций, использовавшиеся в продуктах инвестиционного страхования жизни основными страховщиками, показали умеренно отрицательную динамику.

Аутсайдерами стали облигационные стратегии высокодоходного сегмента с фокусом на развивающиеся рынки - по ним получена отрицательная доходность до 9-10\%. Иными словами, облигационные стратегии тоже сработали для клиентов защитой капитала и уберегли их вложения [4].

При этом облигационные стратегии инвестиционного страхования жизни показали меньшее падение, чем акционные, что естественно, так как облигации менее рискованный инструмент.

Динамика товарных рынков была неоднородной. Драгметаллы выглядели на порядок лучше. Например, одной из лучших инвестиций стал палладий $(+18,6 \%)$, по которому в последние годы на рынке наблюдается недостаток предложения при очень высоком спросе.

В портфеле инвестиционного страхования жизни товарные рынки занимают низкую долю, чем акции и облигации. Наиболее популярны стратегии на золото, нефть, а также комплексные товарные индексы. Последние показали доходность от $-4 \%$ до +4 [4].

На рынке страхования жизни доля банковского канала для продажи страховых продуктов превышает 90\%. Это связано с тем, что страхование жизни - инструмент управления сбережениями граждан наряду с наличными и банковскими депозитами. Таким образом, инвестиционное страхование жизни - это классический финансовый продукт, который проходит стадию своего становления. 


\section{ЛИТЕРАТУРА}

1. Беспалова О. В. Краткосрочная и долгосрочная финансовая политика // Брянск, 2016.

2. Беспалова 0.В., Беспалов Р. А. Актуальные направления развития аутсорсинга в сфере страховых услуг // Интеллект. Инновации. Инвестиции. 2016. № 5. C. 9-12.

3. Савинова Е.А., Ковалерова Л. А. Особенности внедрения новых технологий в финансовом секторе // Наука и бизнес: пути развития. 2018. № 10 (88). C. 107-109.

4. Информационное агентство Банки.ру [Электронный ресурс]. Режим доступа: http://www.banki.ru/ (дата обращения: 23.02.2020)

5. Официальный сайт Банка России [Электронный ресурс]. Режим доступа: http://www.cbr.ru/ (дата обращения: 23.02.2020)

6. Страховой портал «Страхование сегодня» [Электронный ресурс]. Режим доступа: http://www.insur-info.ru/ (дата обращения: 23.02.2020)

7. Bespalova 0.V., Bespalov R. A., Kovalerova L. A., Savinova E. A., Tachkova I. A., Budanova M.V. Innovation-and investment-based development to the Russian insurance system // International Journal of Applied Business and Economic Research. 2017. T. 15. № 11. C. 63-72.

( Б) Беспалова Ольга Васильевна ( bespalovaov@yandex.ru ), Ковалерова Людмила Анатольевна ( kovaleroval@mail.ru ).

Журнал «Современная наука: актуальные проблемы теории и практики»

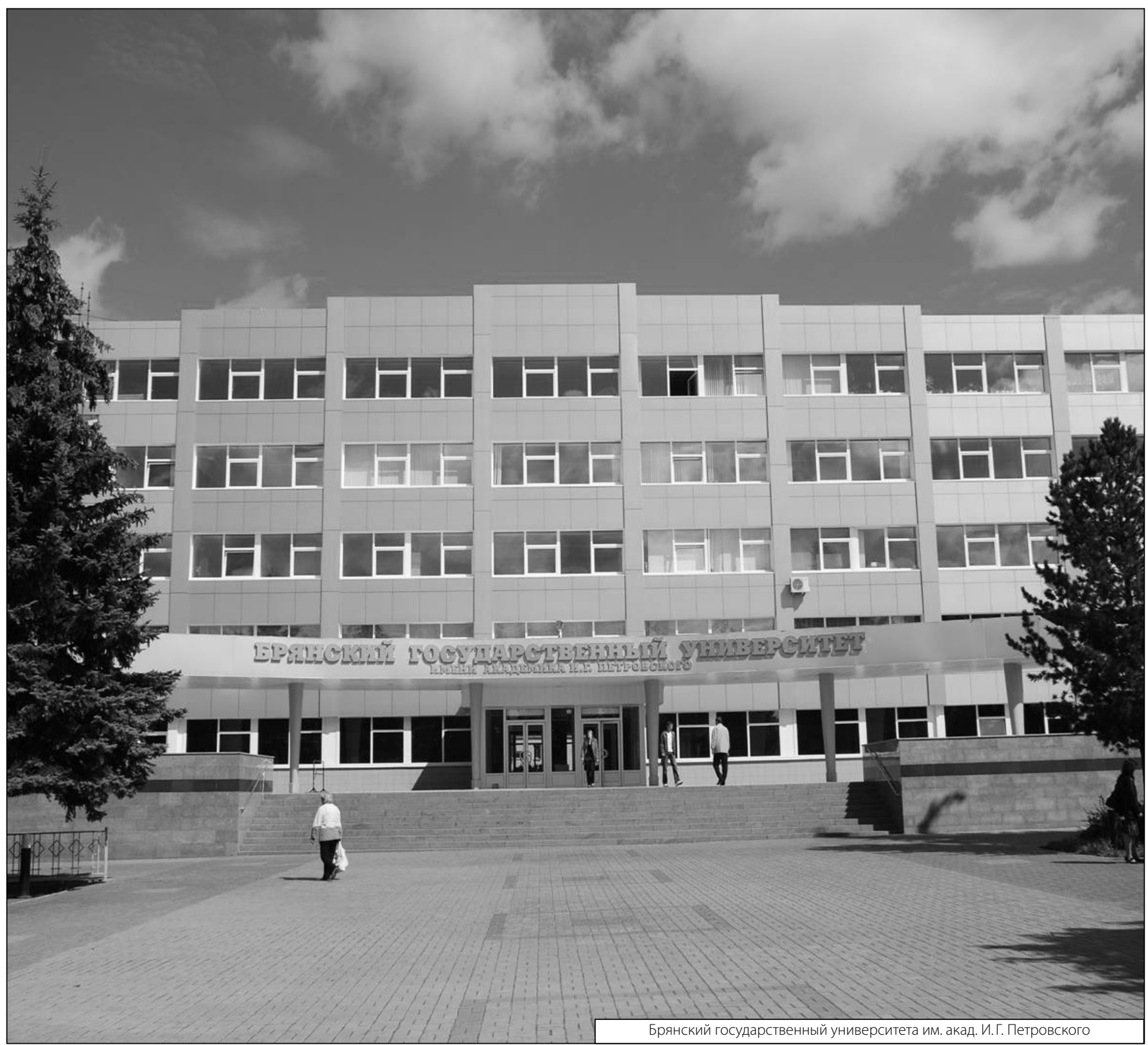

